UDC 821.111(73)По-32

DOI https://doi.org/10.32838/2663-6069/2020.3-2/35

Diordieva $A$. $V$.

Institute of Philology

of Petro Mohyla Black Sea National University

\title{
EDGAR ALLAN POE'S “THE BLACK CAT": A PERVERSE TALE OR A STORY WITH DEEPLY-ROOTED VICTORIAN MORALITY?
}

The article deals with the issue of morality in Edgar Allan Poe's short story "The Black cat". The author offers a comprehensive analysis of various viewpoints that provide an insight into the interpretation of the short story through the prism of morality. The articles emphasizes, that Edgar Allan Poe having lived in extremely challenging times, was consequently torn apart between the impending strict code of morality that everyone was supposed to follow and his own inner demons and vile propensities. The psychological interpretation suggests that the narrator in the act of killing the cat probably revealed his suppressed feelings for his wife who had been "notoriously" known for her docility in sexual domain. One more psychological viewpoint that the authors offers in order to prove the presence of Victorian morality in Poe's discourse is that the behavior of the narrator should seem so horrible and repulsive to the reader that the whole story itself might serve as a deterrence factor for the audience thus advocating the principles of respect to human life and general humanity. The researcher of this paper agrees with other papers in this field that the cat had always been "the surrogate" of the narrator's wife who he always wanted to kill in the first place. In order to get to the depths of the narrator's character, the author utilizes the ideas that Edgar Allan Poe expresses himself in his essay "The Imp of Perverseness" about the primitive dark instinct that lurks inside every human making them commit horrible things just for the sake of committing them. Another viewpoint that the author thoroughly analyzes is the interpretation of "The Black Cat" through the norms of Christian Victorian morality that was all about sins and retribution at the time. According to this interpretation, all abominable deeds that the narrator commits are done purposefully in order to receive a proper severe punishment that the narrator knows he deserves.

Key words: Victorian morality, "The Black Cat", Edgar Allan Poe, "The Imp of Perverseness", "The Image of Man".

Outline of the problem in general and its connection with important scientific or practical tasks. The issue of morality in Edgar Allan Poe's works has been a significant point of controversy among different researchers. Scientists argue whether or not his works exhibit any morality at all or rather are manifests of depravity. Looking at the superficial plots of most his horror stories, it may seem that Edgar Allan Poe is only interested in highlighting and nurturing the darker side of a human. However, this is not necessarily the case. In this paper we will try to analyze various interpretations of "The Black Cat" as well as try to demonstrate that Edgar Allan Poe's works, and specifically "The Black Cat" do reveal some norms of Victorian morality such as sexual restraint and sin repentance.

Analysis of recent articles and publications researching this issue with highlights on previously unresolved parts of the general problem that the article is dealing with. The critical discourse on Edgar Allan Poe's thrilling short stories is not unequivocal. Some critics come to the conclusion: "the narrator in "The Black Cat" is "mad" because his behavior deviates from all the moral maxims in traditional ethics $\langle\ldots\rangle$ his drive ethics is on the side of chaos, madness, and death" [6, p. 569]. For instance, analyzing Poe's short story "The Black Cat" Margaret Wing-Chi Ki clearly states that the story's "narrator is, if not preaching his philosophy of evil ("I am bad and I love to be bad"), then having fun in redefining the ethical order and dissociation of crimes from any sense of right and wrong" [6, p. 570]. Other scholars argue that instead of fixating on issues of morality, Poe "achieves remarkable insights into the irrational defenses of the mind, and into irrationality itself" [5, p. 249]. On the other hand, Robert Shulman in the same article implies that atrocious treatment of the cat, being a surrogate for the narrator's wife, could be explained by the narrator's desire to keep to the Victorian value of "moral restraint" i.d. sexual abstinence. According to Shulman, by "humanizing" the behavior of both cats while speaking about the animal's "loathsome caresses", getting "between the feet" or jumping "upon the knees" [3, p. 9] 
the narrator subconsciously demonstrates his being deeply bothered by his docile and gentle wife's sexual behavior and her "interference with his freedom" [5, p. 257-258].

The goal of the article. Considering the lack of clarity in the question of morality in Edgar Allan Poe's prose, this paper intends to investigate the way Poe does reveal his sense of Victorian values such as sexual restraint and self-control and therefore can be considered a man of high Christian morality.

Presentation of the main material of the research with proof of the obtained scientific results. Edgar Allan Poe had to live and create in the controversial time of Queen Victoria's reign (1837-1901). The main characteristic of the epoch was its heavily contradictory phenomena of everyday social life. On the one hand, everybody was supposed to live up to enormously high standards of moral conduct and dignity. On the other hand, social negative manifestations of inner inconsistencies like widespread prostitution and engaging children in hard labor were a staple at that time. Poe's short story "The Black Cat" in many ways reflects those contradictions and depicts psychological torments of a person torn between his inner demons and the imperative to preserve his morality. The narrator and the main character of the story first described as a gentle, petloving personality, gradually transforms into literally a villain, becoming "more moody, more irritable, more regardless of the feelings of others" [3, p. 4] after he gets married and develops passion for alcohol. As Shulman sagaciously conjured, the reason for this transformation could have been the relationship with his wife. The narrator neither gives any account of him and his wife having children nor provides any other information about his wife except for her being animal-loving and docile. The reader can surmise that the narrator was avoiding having sexual intercourse with his wife and tried to release the subsequent tension through his aggressive behavior towards his numerous pets and wife, which, by the way was not illegal at the time. Being a man of his time with moral obligations impending on him, the narrator tried to mute his natural instincts and suppress the very thought of them. Accepting Shulman's assumption that both cats must have been for the narrator "the surrogate for his wife" [5, p. 257], one can suppose it was her who the narrator wanted to kill in the first place. Seeing his wife as the source of constant temptation to cross the line of the socially privileged code of conduct, the narrator subconsciously gravitates to destroying her. The paradox of the narrator's chimerical morality consists in the fact that he would rather commit a deadly crime of murder than surrender to what is generally considered improper behavior.

Another possible viewpoint in discussing Poe's morality could be the suggestion that Poe's respect of animals is greater than that of humans supposedly, because the former are not prone to human vices like substance abuse and improper temptations. However, perverted this idea might be, the narrator in "The Black Cat" is obviously more worried about mutilating and killing of his favorite pet than about murdering his own innocent spouse. Thus, in the morning next to taking out the animal's eye the narrator experiences, although "feeble and "equivocal" "a sentiment half of horror, half of remorse" [3, p. 5] while the murder of his wife presents him with no other concerns than hiding her body. Having walled the dead body, the narrator feels "satisfied that all was right" $[3, p .12]$. The most plausible explanation is again the assumption that it was his wife, the source of sin, carnal temptations and the true reason for his partiality to alcohol and subsequent bad temper, who the narrator wanted to kill in the first place without being consciously aware of it. The days following the murder the narrator surprisingly feels "the blissful sense of relief" and "breathes as a free man" [3, p. 12], although he claims it was because the cat was no longer there. Thus, the reasoning about the anatomy of a dark state of mind present in Poe's short story could be further developed by the claim that the power of the dark mind is used by the narrator's psyche to suppress his natural instincts because the accepted moral values of the time demand from him to do so and subsequently the narrator looks for ways to let the tension go through wayward displacement of "wife-cat" roles.

One more viewpoint one might embrace to prove the presence of Victorian morality in Poe's discourse is the claim that the behavior of the narrator should seem so horrid and repulsive to the reader that the story itself should serve as a deterrence factor for the wider public thus advocating the principles of respect to human life and general humanity. Poe masterfully shows that even if outer manifestations of a person's life are fairly dignified and proper, genuine evil seed will inevitably germinate unless the person truly works on their personality and moral conduct. The tragedy of the narrator is enhanced by the plot twist in which he is actually given the second chance with the second cat or karmic reincarnation of the first one. The second cat would have died even a more horrible death than the first but for the narrators' animal-loving wife who stood up for the poor thing and paid for it with her life. 
Through horror and satire Poe explores and debunks the myth of an ideal Victorian man, embodying valid norms and virtues as described in, for instance, George Mosse's book "The Image of Man". The book gives a detailed account of what was supposed to be a model male of Victorian epoch. The main attributes of an ideal man are restraint and self-control, complimenting a man's bodily perfection [2, p. 94]. The man's body, being a locus of restraint, had to be tamed through harsh discipline and hardening of the will-power [2, p. 94]. In one of his most controversial and assumedly immoral short stories "The Black Cat" Poe actually demonstrates what can happen to the psyche of a male constantly having to suppress his sexual desires and overcome his emotional weakness. Through the prism of this reading "The Black Cat" becomes a warning and the herald of new type of morality, different from that forced during the Victorian era. Despite its seemingly pervert content, Poe's short story is, in fact, an apologist tale of genuine humanity, the one where a human being's primarily need should be love instead of denial of love. In such an interpretation "The Black Cat" contains more humane morality than all of the Victorian moral treatises laid end to end. According to Mosse's image of an ideal man, any male should suppress the forbidden desires with self-control and physical exercise [2, p. 100]. That was probably what the narrator in "The Black Cat" needed along with acceptance of his physical and emotional needs. The result of the narrator's denial of those needs was the "spirit of perverseness" that he called an "unfathomable longing to do wrong for the wrong's sake". This "longing" is not in the least surprising if we assume that this black cat, extraordinary large and beautiful, can symbolically represent the narrator's true emotional needs to love and be loved that he had to continuously restrain due to the widespread image of a man as someone who should subdue his sentimentality. No wonder the narrator feels terrible while killing the animal "with the tears streaming from the eyes and with the bitterest remorse at the heart" [3, p. 6].

Therefore, the whole transformation of the main character can be plausibly explained through this symbolic interpretation of the cat as the narrator's emotional constituent. In the very beginning of the story he recollects that as a child he was "known for the humanity and docility of his disposition", his "tenderness of heart" being so "conspicuous" that his peers would often make a mock of him [3, p. 3]. However, this unusual "tenderness" and over-emotionality contradicted the way the society of the time viewed young boys and men. In Mosse's description of the epoch's ideal a man had to struggle both with his sentimentality and bodily desires: "real men don't cry" [2, p. 4]. Consequently, as the narrator gets married and takes a lot of pets into his house, his emotional response might have grown and that must have been unacceptable by Victorian morals. Resorting first to alcohol abuse and then to physical aggression the narrator tries to come to terms with his body and soul receiving mixed messages all the time. The tragedy of the $19^{\text {th }}$ century man is that alcoholism and aggression were probably considered lesser evils than a simple human need to freely express his sentiments and satisfy basic physical needs. Symbolical killing of the cat as an incarnation of his emotional side can be interpreted as the narrator's sacrificial desire to conform to the norms of Victorian morality.

Another interpretation of the cat's murder can be found in purely Christian terms of morality. After the narrator mutilates the pet by cutting his eye, he feels deep remorse and guilt and being naturally a genuinely religious person, he "consummates" his sin by completing the injury to the poor animal. At first, he states that he did so only because of an "unfathomable longing to do wrong only for the wrong's sake", but later in the same paragraph the reader finds out the true reason for the horrible act. Feeling sinful and guilty, the narrator desperately and passionately seeks retribution from "the Most Merciful and Most Terrible God" [3, p. 6]. However, mercy is not what the narrator wants. His sentiment of guilt is so deep and overwhelming that he wants to be placed with his act of utmost cruelty "even beyond the reach of the infinite mercy" of the Merciful God $[3$, p. 6]. That is the true reason for murdering the beloved pet - love and search for proper punishment. The narrator kills the cat to make sure he commits the most horrible sin and cannot avoid proper retribution. His feeling of guilt is so deep and strong that the most adequate way to deal with it is for a genuinely religious person with Christian morality of inflicting no harm to others is seeking for and accepting the deserved punishment. The narrator makes the choice of murder because he knows that the most severe punishment for him will be living with the burden of committing the crime of murder against the creature who truly loved him. Another Christian reference here is the notion of unquenchable fire of God, the one that burns until destroys its object, the lost soul, completely [1]. The fire literally takes place in the narrator's house on the very night of the cat's murder. It literally wipes his house clean. 
Whether coincidence or the mystic interference of God this fire leaves just one wall intact, the one on which the image of the dead cat clearly stands out. There is no doubt that Poe refers to the Biblical notions because of his actually high appreciation of true humane values of morality. Whatever obvious the signs must be, the narrator seems to ignore them completely whether by natural simple-mindedness or purposeful neglect. He misses the chance to atone his sin with the second cat and is finally wallowed in vice with the axing of his wife and walling her body up in the cellar.

One more interpretation of the narrator's vile behavior can be found in E. A. Poe's own essay "The Imp of the Perverse" where he repeatedly emphasizes that there is this primitive basic instinct within a human that imposes its will upon us no matter how well we understand that what we are about to do is utterly wrong: "through its promptings we act, for the reason that we should not. In theory, no reason can be more unreasonable, but, in fact, there is none more strong. With certain minds, under certain conditions, it becomes absolutely irresistible" [4, p. 2]. Thus, this "absolutely irresistible urge" possesses the narrator of "The Black Cat" when his cat, frightened by his drunk owner, bites the narrator's hand. The narrator describes this urge almost in the same manner as Edgar Allan Poe himself - as a demon (imp) that supersedes a person's true self and makes them do something utterly outrageous: "The fury of a demon instantly possessed me. I knew myself no longer. My original soul seemed, at once, to take its flight from my body; and a more than fiendish malevolence, gin-nurtured, thrilled every fibre of my frame" [3, p. 5]. This powerful longing to act against all moral imperatives is vividly compared with inexplicable yet irresistible impulse of a person standing on the edge of a cliff to jump into the abyss: "And because our reason violently deters us from the brink, therefore do we the most impetuously approach it. There is no passion in nature so demoniacally impatient, as that of him who, shuddering upon the edge of a precipice, thus meditates a plunge" [4, p. 3]. Assumedly, not all the people who experience these disturbing urges while standing at the precipice do take a plunge, so when Edgar Allan Poe says that the imp of the perverse is especially powerful "with certain minds, under certain conditions", he probably means the persons like the narrator of "The Black Cat" who behave in the most abominable way being absolutely aware of that but without any means to stop themselves.

Conclusions. Summarizing everything said before, it becomes obvious that Edgar Allan Poe' prose cannot be seriously taken as pervert or lacking integrity. On the contrary, many arguments show that he, in fact, was a man of high morality. Among those arguments is irrefutable evidence that his character from "The Black Cat" story was trying to live up to Victorian values such as sexual and emotional restraint, resulting though in rather negative consequences. By demonstrating his character's degrading lifestyle and behavior and finally his succumbing to deadly sins, Poe masterfully achieves another goal - many of the readers are certain to be deterred by the illfate that befell the narrator of "The Black Cat" and respectively are unlikely to take him as a role model. Another possible way to defend the thesis that Poe does propagate morality in his prose is interpreting the story in Christian terms of sin and retribution. In this reading all the narrators seemingly illogical and purposelessly atrocious acts can be looked upon as deeds driven by the sense of guilt and search for adequate punishment. Everything the narrator does - mutilates and then kills the cat, lets his house burn down, attempts to kill the second cat and finally murders his wife, - in the light of biblical interpretation can be presented as wandering of the lost soul in its longing for severe but fair retribution. Finally, the narrators' actions could also be interpreted as the influence of the dark and powerful impulse lurking inside every human soul, which certain individuals under certain circumstances are simply unable to resist.

\section{References:}

1. Date C. The Fire Is Not Quenched: Annihilation and Mark 9:48. URL: http://rethinkinghell.com/2012/11/20/ the-fire-is-not-quenched-annihilation-and-mark-948-part-2/.

2. Moss J. Image of Man: The Creation of Modern Masculinity. Oxford : Oxford University Press, Incorporated, 1998. $240 \mathrm{p}$.

3. Poe E. The Black Cat. 1843. URL: https://www.ibiblio.org/ebooks/Poe/Black_Cat.pdf.

4. Poe E. The Imp of the Perverse. URL: file:///C:/Users/User/Downloads/the-works-of-edgar-allan-poe-079the-imp-of-the-perverse.pdf.

5. Shulman R. Poe and the Powers of the Mind. ELH. 1970. Pp. 245-262.

6. Wing Chi Ki M. Diabolical Evil and "The Black Cat". Mississippi Quarterly. 2009. No. 62. Pp. 569-589. 


\section{Діордієва А. В. «ЧОРНИЙ КІТ» ЕДГАРА АЛЛАНА ПО: КАЗКА ПРО СТРАШНІ ЗЛОЧИНИ ЧИ} ПОВЧАЛЬНА ІСТОРІЯ 3 ГЛИБОКО ПРИХОВАНОЮ МОРАЛЛЮ?

У статті йдеться про проблему моралі в новелі Едгара Аллана По «Чорний кіт». Автор пропонує всебічний аналіз деяких точок зору, які дають уявлення про різні інтерпретації новели через призму моралі. У статтях підкреслюється, що Едгар Аллан По, який жив у надзвичайно складні часи, розривався між всепроникним суворим кодексом моралі, якого повинен був дотримуватися кожен, та його власними внутрішніми демонами та аморальними схильностями. Психологічне тлумачення говорить про те, що оповідач, імовірно, намагався пригнічувати почуття до своєї дружини, яка була «горезвісно» відома своєю покірністю у сексуальній сфері. Ще одна психологічна точка зору, яку пропонує автор статті, щоб довести наявність вікторіанської моралі в дискурсі Е. А. По, полягає в тому, що поведінка оповідача повинна виглядати настільки жахливою та відразливою для читача, що сама новела може слугувати фактором стримування для аудиторії, стверджуючи таким чином принципи поваги до людського життя та загальної людяності. Автор иієї роботи погоджується з іншими дослідженнями в цій галузі, ще кіт завжди ніби «заміщав» собою дружину оповідача, і саме іï оповідач і хотів вбити із самого початку. Для того щоб дістатися до глибини характеру оповідача, автор використовує ідеї, які сам Едгар Аллан По висловлює у своєму нарисі «Біс протиріччя» ("The Imp of the Perverse") про примітивний темний інстинкт, який ховається всередині кожної людини, змушуючи ї̈ робити жахливі речі тільки заради їх вчинення. Інша точка зору, яку автор всебічно аналізує, - це тлумачення «Чорного кота» через норми християнської вікторіанської моралі, які в ті часи стосувалися в основному гріхів та покарання. Згідно з иією інтерпретацією, всі огидні вчинки, які здійснює оповідач, робляться цілеспрямовано, щоб отримати належне суворе покарання, на яке оповідач знає, що заслуговує.

Ключові слова: вікторіанська мораль, «Чорний кіт», Едгар Аллан По, «Біс Протиріччя», «Образ Людини». 